\title{
INVESTIGATION OF THE CUTTING FORCES AND SURFACE ROUGHNESS IN MILLING CARBON-FIBER-REINFORCED POLYMER COMPOSITE MATERIAL
}

\author{
PREISKAVA SIL REZANJA IN HRAPAVOSTI POVRŠINE PRI \\ REZKANJU KOMPOZITNEGA POLIMERNEGA MATERIALA, \\ OJAČANEGA Z OGLJIKOVIMI VLAKNI
}

\author{
Senol Bayraktar¹, Yakup Turgut ${ }^{2}$ \\ ${ }^{1}$ Recep Tayyip Erdogan University, 53100 Rize, Turkey \\ ${ }^{2}$ Gazi University, Faculty of Technology, Manufacturing Engineering, 06500 Teknikokullar, Ankara, Turkey \\ senol.bayraktar@erdogan.edu.tr, senolbyrktr@gmail.com
}

Prejem rokopisa - received: 2015-07-03; sprejem za objavo - accepted for publication: 2015-07-27

doi:10.17222/mit.2015.199

\begin{abstract}
In this study, milling of a carbon-fiber-reinforced polymer composite material (CFRP) was investigated experimentally using various carbide end mills. The input parameters included the spindle speed, feed rate and cutting tool, whereas the output parameters were defined as the cutting force and surface roughness. The experimental design was based on the Taguchi $L_{18}$ $\left(6^{1} \times 3^{2}\right)$ orthogonal array. In the tests, six different carbide end mills with a $10 \mathrm{~mm}$ diameter were used: an uncoated two-flute $30^{\circ}$ helix-angled one; carbide-coated two-, three- and four-flute $30^{\circ}$ helix-angled ones; and TiAl-coated three- and four-flute $45^{\circ}$ helix-angled ones. The cutting parameters included three different feed rates $(0.03,0.06,0.09) \mathrm{mm} /$ tooth and three different spindle speeds $(3800,4800,5800) \mathrm{min}^{-1}$. The Taguchi method was applied to select the most appropriate cutting parameters (cutting force, feed rate) for the tests. With the analysis of variance (ANOVA), the feed-rate factor was found to be the most effective one among these parameters (cutting forces and surface roughness). The results of the experiments showed that the uncoated carbide end mill had a better performance in terms of the cutting forces and surface roughness. Besides, it was also seen that the surface roughness increases with the increasing number of flutes and helix angle.
\end{abstract}

Keywords: CFRP, cutting forces, surface roughness, Taguchi method, ANOVA

$\mathrm{V}$ študiji je bil eksperimentalno proučevano rezkanje polimernega kompozitnega materiala, ojačanega z ogljikovimi vlakni (CFRP) z uporabo rezkarjev z različnim karbidnimi nanosi. Vhodni parametri so vključevali hitrost vrtenja vretena, hitrost podajanja in rezalno orodje, medtem ko sta bila izhodna parametra sila rezanja in hrapavost površine. Zasnova eksperimenta je temeljila na Taguchi $L_{18}\left(6^{1} \times 3^{2}\right)$ ortogonalni matriki. Pri preskusih je bilo uporabljenih šest različnih cilindričnih rezkarjev s premerom $10 \mathrm{~mm}$, dvorezni s kotom spirale $30^{\circ}$ brez nanosa, dvo, tri in štirirezni s kotom spirale $30^{\circ}$ prekriti s karbidi ter tri- in štirirezni rezkar s kotom spirale $45^{\circ}$ in nanosom TiAl. Uporabljeni parametri rezanja so vključevali tri različne hitrosti podajanja $(0.03,0.06,0.09) \mathrm{mm} / \mathrm{zob}$ in tri različne hitrosti vrtenja vretena $(3800,4800,5800) \mathrm{min}^{-1}$. Za izbiro najprimernejših uporabljenih parametrov (sila rezanja, hitrost podajanja), je bila uporabljena Taguchi metoda. Med uporabljenimi parametri (sila rezanja in hrapavost površine) se je pokazalo, s pomočjo analize variance (ANOVA), da je hitrost podajanja najbolj vpliven faktor. Rezultati preskusov so pokazali, da ima rezkar brez nanosa karbida, boljše zmogljivosti glede na sile rezanja in hrapavost površine. Poleg tega se je pokazalo, da hrapavost površine narašča z večanjem števila utorov in kota vijačnice.

Ključne besede: CFRP, sile rezanja, hrapavost površine, Taguchi metoda, ANOVA

\section{INTRODUCTION}

In the aviation and automotive industry, processing of composite materials constitutes the great majority of the machining operations. On the composite materials, machining operations such as milling, drilling, edge cutting, turning and grinding are practiced. In these applications, some undesired situations such as tool wear, delamination and fiber rupture are encountered due to non-uniform structures of composite structures. The reasons for these situations are unsuitable cutting parameters and cutting conditions. ${ }^{1}$

Milling is a widely used process in the machining of CFRP materials. A composite material, which is taken out of the mold, cannot be used directly. Certain removals from the material surface must be made with respect to the previously specified dimensions and tolerances.
The milling process, which provides a surface of desired quality, plays a significant role in the shaping of the CFRP materials. Besides, the surface roughness also plays an effective role in the optimization of cutting parameters and tool geometries because of its significant effect on the dimension accuracy and production costs., ${ }^{2,3}$ The surface roughness is one of the most important factors in machining, influencing the manufacturing performance. The realization of the desired function of machine parts (in contact with each other) achieved by spending minimum energy depends on the surface roughness. ${ }^{4}$ In order to achieve the desired quality of a machined surface, it is necessary to understand the mechanisms of material removal and the kinetics of machining processes affecting the performance of cutting tools..$^{5,6}$ 
Previous researchers investigated the effect of the rotational speed and feed rate on the cutting forces in the milling of a polymer carbon-fiber composite material, using time series and the empirical relationship for the amplitude of the cutting force $\left(F_{x}\right)$ to find the highest coefficient of delamination $\left(R^{2}\right) .{ }^{7}$ However, if all three components of the total forces $\left(F_{x}, F_{y}, F_{z}\right.$ in the $x, y, z$ directions, respectively) had been taken into account, the coefficient of delamination could have been calculated more precisely. The obtained vibration graphs were examined according to the test results and it was found that there was a decrease in the cutting forces with an increase in the number of revolutions, while the cutting forces increased as the feed-rate values increased. They evaluated the surface roughness and delamination in the milling of a $55 \%$ fibered and $0^{\circ} / 90^{\circ}$ angled carbonfiber-reinforced composite material, using the Taguchi method, ANOVA and multiple regression analysis with respect to the cutting speed and feed-rate parameters. After the measurement of the maximum width of damage $\left(W_{\max }\right)$ caused by the material, the damage normally assigned to the delamination factor $\left(F_{\mathrm{d}}\right)$ was determined. This factor is defined as the ratio between the maximum width of damage $\left(W_{\max }\right)$ and the width of cut $(W)$. The delamination-factor value was calculated with Equation (1):

$$
F_{\mathrm{d}}=\frac{W_{\max }}{W}
$$

In their work, it was observed that the surface roughness and delamination factor increased depending on the increased feed rate and cutting speed. ${ }^{5}$ They also investigated the effects of the cutting-tool helix angle, the coating process and the cutting force on the delamination factor and surface roughness in their experimental study. An experimental study on the optimum machining of fiber-reinforced composite materials was made. It was specified that a higher cutting speed and a lower feed rate had to be used at a constant depth of cut in order to decrease delamination and the fiber amount and fiber angles of the material were also important to obtain the optimum results. They concluded that the upper and lower layers of fiber-reinforced composite materials have the biggest influence on the surface quality when cutting these materials. ${ }^{8}$ Thus, the milling of these materials requires a very sharp cutting edge, which is particularly necessary for solid carbide millig cutters. They investigated the cutting forces, created in the helical and orthogonal machining of multi-directional $\left(60^{\circ} / 0^{\circ} / 120^{\circ}\right)$ and unidirectional $\left(60^{\circ}\right)$ CFRP material, using the artificialneural-network (ANN) method. In their work, it was emphasized that mechanistic modeling approaches are valid for machining FRPs and predictive capabilities of cutting forces can calculated for a rotating helical milling tool and for any fiber orientation using ANNs. ${ }^{1}$ They also used different numbers of flutes/edges or helixangled cutting tools and different fiber orientations for modelling approaches.
The effect of different cutting parameters (cutting speed, feed rate and tool geometry) on the surface roughness in the machining of glass-fiber-reinforced polymer composite material was investigated. In all of the cutting tests, depending on the increase in the feed rate, an increase in the surface roughness was observed and the best surface quality was obtained with a four-flute carbide end mill at the highest cutting speed and the lowest feed rate. Moreover, according to their study it is evident that the surface roughness increased with the increasing number of flutes. ${ }^{9}$ However, the surface roughness must increase with the increasing number of flutes due to the contact unit time. Thus, this situation can bring about an increase in the temperature in the cutting zone. ANOVA was used to identify significant factors using the grey relational grade value. According to the ANOVA results, it is clear that the fiber orientation angle (51.00 per cent) has the main influence on the milling of GFRP composites, followed by the helix angle (19.54 per cent), the feed rate (14.37 per cent) and the spindle speed (1.56 per cent). ${ }^{10}$ They also pointed out different optimization approaches and multiple regression analysis in their study. In this way, they were able to reveal more realistic results.

In another study, the hole delamination created during the drilling of FRP plates was shows, using a digital-analysis-based approach. Since a digital image is considered as the matrix where columns and rows identify one point of the image, the value corresponds to the luminous intensity of this point. The image processing produces satisfactory results, allowing an observation and analysis of the details from the digitalized image. Thus, in their work, the digital image of the damage area is used to characterize its extension at the hole entrance and exit. As a result, a comparison of the created delamination factors was made using the digital-analysis approach according to the cutting speed and feed rate in the tests. An increase in the delamination factor was found to depend on the increase in the cutting speed and feed rate. ${ }^{11}$

This digital-analysis-based approach can also be applied to the milling of FRP materials using different cutting parameters and tool geometries. The researchers developed a delamination-prediction model using a multilayer feed-forward ANN and a training EBPT algorithm. They claimed that the developed ANN model showed a good correlation for both the training and testing data sets and that the delamination decreased with an increase in the number of revolutions, while it increased when a drill of a bigger tip angle was used. ${ }^{12}$ Moreover, they also stated that at higher feed-rate values the drill could not function properly due to the coherence on the tool edges, causing an increase in the delamination. They developed a mathematical analysis method for the analysis of delamination in drilling FRPs. The delamination was measured using the ultrasonic C-scan method. They claimed that as the tool wear increased, the feed-rate factor increased. Furthermore, the feed-rate 
factor decreased with a decrease in the number of revolutions and increased with an increase in the feed-rate values. ${ }^{13}$ In another study, chip-formation mechanisms were used, the Taylor tool-wear constants were determined and the surface roughness was measured with respect to the cutting speeds and feed rates. Moreover, the authors observed an increase in the tool wear and surface roughness due to the increase in the cutting speed and fiber angle, depending on the constant feed rate in turning. ${ }^{14}$ They investigated the effect of the fiber orientation on the grindability of CFRPs. They claimed that the surface roughness increased with the increase in the fiber angle and chip formation. The grinding forces and surface integrity were also found to depend on the fiber orientations in the grinding of an FRP..$^{15}$

In this study, the effects of cutting parameters and cutting-tool properties (coated or uncoated, the helix angle, the number of flutes) on the cutting force and surface roughness were experimentally investigated for the $45^{\circ}$ orientation angle in the milling of CFRP. Besides, the experimental results were optimized using the Taguchi method and the most effective cutting parameters (cutting speed and feed rate) for the cutting force and surface roughness were determined through a variance analysis (ANOVA).

\section{EXPERIMENTAL PROCEDURE}

\subsection{Materials and method}

In the milling of a CFRP material, six different carbide end mills with a $10 \mathrm{~mm}$ diameter were used: an uncoated two-flute $30^{\circ}$ helix-angled mill; two-, threeand four-flute $30^{\circ}$ helix-angled mills; and TiAl-coated, three- and four-flute $45^{\circ}$ helix-angled carbide end mills. For the tests, coated carbide end mills of the GC1630 quality, PVD-coated with TiAl, with a coating thickness of 3-5 $\mu$ and made of fine-particle cemented carbide were used. The technical properties of the end mills used in the tests are given in Table $\mathbf{1}$.
The tests were made at three different revolutions: 3800, 4800, $5800 \mathrm{~min}^{-1}$ and three different feed rates: $0.03,0.06,0.09 \mathrm{~mm} / \mathrm{tooth}$, and at a $1 \mathrm{~mm}$ depth of cut (Table 2).

Table 2: Cutting parameters

Tabela 2: Parametri rezanja

\begin{tabular}{|c|c|c|}
\hline $\begin{array}{c}\text { Spindle speed } \\
\left(\mathrm{min}^{-1}\right)\end{array}$ & $\begin{array}{c}\text { Feed rate } \\
(\mathrm{mm} / \text { tooth })\end{array}$ & $\begin{array}{c}\text { Depth of cut } \\
(\mathrm{mm})\end{array}$ \\
\hline $3800,4800,5800$ & $0.03,0.06,0.09$ & 1 \\
\hline
\end{tabular}

A CFRP composite material (polymer matrixed) was used in the tests. In accordance with ASTM D 792, the density test result as well as the mechanical, thermal and electrical properties of the CFRP material are given in Table 3.

Table 3: Physical properties of the material used in the tests according to ASTM D 792

Tabela 3: Fizikalne lastnosti materiala uporabljenega pri preskusih po ASTM D 792

\begin{tabular}{|c|c|c|c|c|c|c|c|}
\hline 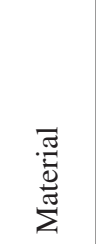 & 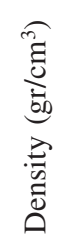 & 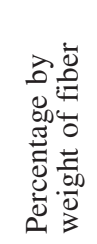 & 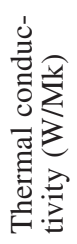 & 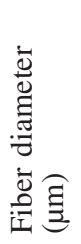 & 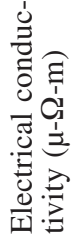 & 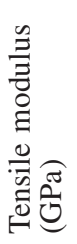 & 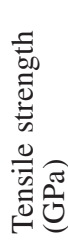 \\
\hline CFRP & 1.59 & $74.6 \%$ & 5 & 7 & 18 & 231 & 3.75 \\
\hline
\end{tabular}

In Figure 1, the fiber orientation angles of the material used in the tests are given. The lay-up sequence of the CFRP was $\left[0^{\circ} / 45^{\circ} / 90^{\circ} / 45^{\circ} /-45^{\circ} / 90^{\circ} / 45^{\circ} / 0^{\circ}\right]$; it was created as a laminate. The CFRP composite used for the milling studies had a thickness of $15 \mathrm{~mm}$.

The cutting tests were carried out on a Johnford VMC-850 CNC vertical machining center. In order to obtain the optimum results the Taguchi orthogonal array was used for specifying suitable factors and levels from the cutting parameters.

Table 1: Coated and uncoated carbide end mills used in the tests

Tabela 1: Karbidni rezkarji, z nanosom in brez nanosa, uporabljeni pri preskusih

\begin{tabular}{|c|c|c|c|c|c|c|c|}
\hline Cutting tool & $\begin{array}{c}\text { Cutting-tool } \\
\text { manufacturer } \\
\text { code }\end{array}$ & $\begin{array}{c}\text { Taguchi } \\
\text { cutting-tool } \\
\text { code }\end{array}$ & $\begin{array}{c}\text { Diameter } \\
\text { (mm) }\end{array}$ & $\begin{array}{c}\text { Number of } \\
\text { flutes }\end{array}$ & $\begin{array}{c}\text { Helix } \\
\text { angle }\end{array}$ & $\begin{array}{c}\text { Helix } \\
\text { length } \\
\text { (mm) }\end{array}$ & $\begin{array}{c}\text { Cutting- } \\
\text { tool length } \\
\text { (mm) }\end{array}$ \\
\hline $\begin{array}{c}\text { TiAl-coated } \\
\text { carbide }\end{array}$ & $\begin{array}{c}\text { R216.32-10030- } \\
\text { AC19P }\end{array}$ & (b) & 10 & 2 & $30^{\circ}$ & 19 \\
\hline $\begin{array}{c}\text { Uncoated } \\
\text { carbide }\end{array}$ & $\begin{array}{c}\text { R216.32-10030- } \\
\text { AC19A }\end{array}$ & (a) & 10 & 2 & $30^{\circ}$ & 19 \\
\hline $\begin{array}{c}\text { TiAl-coated } \\
\text { carbide }\end{array}$ & $\begin{array}{c}\text { R216.33-10030- } \\
\text { AC19P }\end{array}$ & (e) & 10 & 3 & $30^{\circ}$ & 19 & 72 \\
\hline $\begin{array}{c}\text { TiAl-coated } \\
\text { carbide }\end{array}$ & $\begin{array}{c}\text { R216.33-10045- } \\
\text { AC19P }\end{array}$ & (f) & 10 & 3 & $45^{\circ}$ & 19 & 72 \\
\hline $\begin{array}{c}\text { TiAl-coated } \\
\text { carbide }\end{array}$ & $\begin{array}{c}\text { R216.34-10030- } \\
\text { AC22N }\end{array}$ & (d) & 10 & 4 & $30^{\circ}$ & 22 & 72 \\
\hline $\begin{array}{c}\text { TiAl-coated } \\
\text { carbide }\end{array}$ & $\begin{array}{c}\text { R216.34-10045- } \\
\text { AC22N }\end{array}$ & (c) & 10 & 4 & $45^{\circ}$ & 22 \\
\hline
\end{tabular}




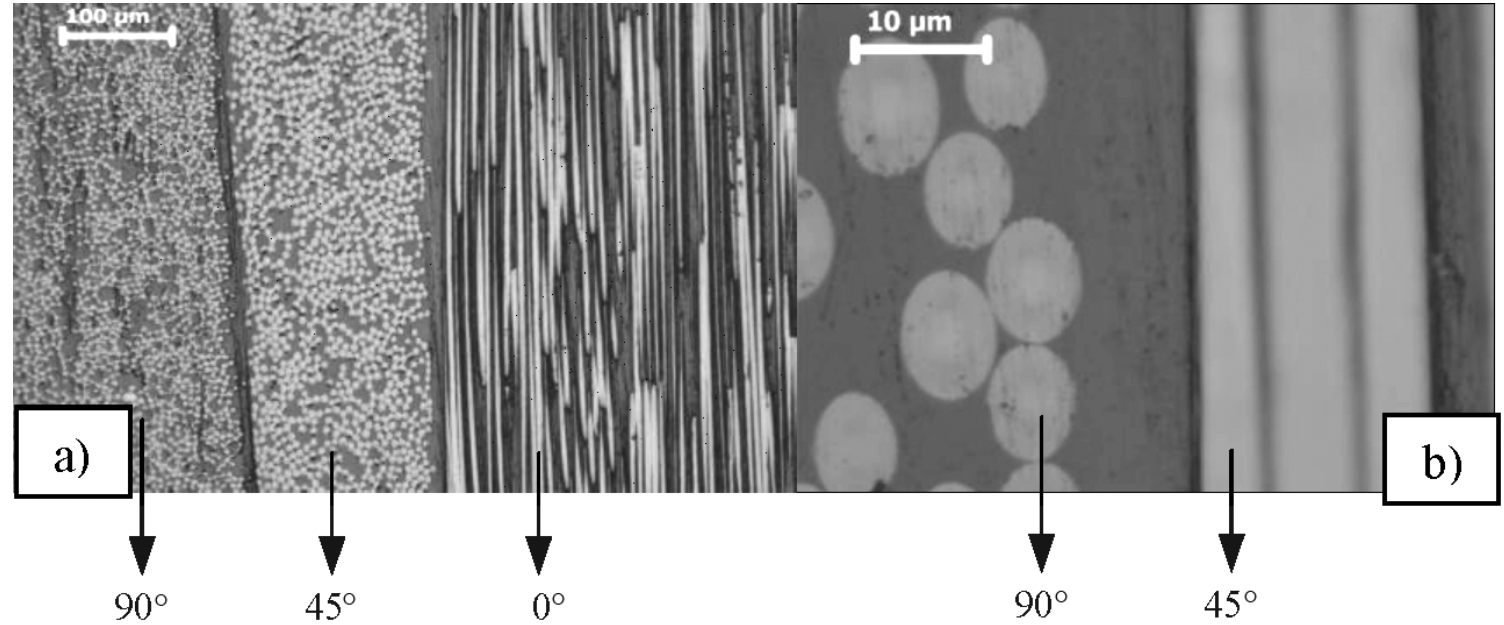

Figure 1: Scanning-electron-microscope (SEM) images of the materials used in the tests Slika 1: Pregled materialov uporabljenih pri preskusih (SEM)

After each machining operation, surface-roughness $\left(R_{\mathrm{a}}\right)$ measurements were made using a surface-roughness measurement device called Mahr Perthometer M1. At least three points were measured to obtain the surfaceroughness values. Cutting forces were measured with a KISTLER 9257B type dynamometer and a KISTLER 5070A type amplifier. The cutting-force values measured with the dynamometer were transferred to the computer digitally and graphically using the Dynoware software. The cutting and feed-rate direction used in the tests are given in Figure 2 and a schematic representation of the experimental set-up is given in Figure 3.

The orientation of the resultant force with respect to the cutting direction is defined with Equation (2):

$$
\lambda_{\mathrm{e}}=\tan ^{-1}\left(\frac{F_{\mathrm{t}}}{F_{\mathrm{c}}}\right)
$$

The resultant orientation signifies the magnitudes of $F_{\mathrm{c}}$ and $F_{\mathrm{t}}$, being relative to each other. The thrust force is greater than the principal force (the cutting force) for fiber orientation angles larger than $45^{\circ}$. Contrary to the cutting-force behavior in metal cutting, the thrust force is found to be higher than the corresponding principal force for fiber orientations $\left(0^{\circ}<\theta \leq 75^{\circ}\right)$, except for the data
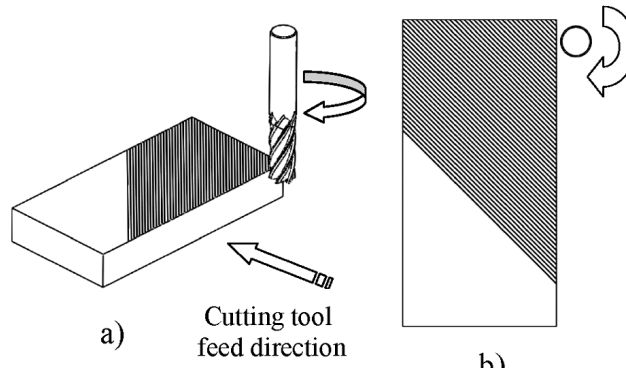

b)

Figure 2: $45^{\circ}$ fiber orientation and rotation direction of the cutting tool: a) isometric, b) top view

Slika 2: $45^{\circ}$ orientacija vlaken in smer rotacije rezilnega orodja: a) izometrično. b) pogled $\mathrm{z}$ vrha taken from some investigations. ${ }^{16,17}$ In general, the thrust force exhibited a more complex behavior than the principal force. An increase in the thrust force is exhibited when cutting small positive fiber orientations; then the thrust force decreases with further increase in the fiber orientation.

The chip-formation mode in cutting positive fiber orientations $\left(0^{\circ}<\theta<90^{\circ}\right)$ was described previously as the fiber-cutting mode, which consists of fiber cutting by compression shear followed by chip flow upward on the rake face by interlaminar shear along the fiber-matrix interface. It was noted that this type of chip formation is similar (only in the appearance because of the absence of plastic deformation) to the chip formation by shear in metal cutting. In these cases, the principal (cutting) force $F_{\mathrm{c}}$ and the thrust force $F_{\mathrm{t}}$ can be resolved into a shear force, $F_{\mathrm{s}}$, acting along the shear plane, and a normal force, $F_{\mathrm{n}}$, acting on the shear plane as shown in Figure 4 and with Equations (3) and (4), respectively. It is noted here that the shear plane cutting FRPs is generally found to coincide with the plane of the fibers for fiber orientations $\left(0^{\circ}<\theta<90^{\circ}\right)$ :

$$
\begin{aligned}
& F_{\mathrm{s}}=F_{\mathrm{c}} \cos \theta-F_{\mathrm{t}} \sin \theta \\
& F_{\mathrm{n}}=F_{\mathrm{c}} \sin \theta-F_{\mathrm{t}} \cos \theta
\end{aligned}
$$



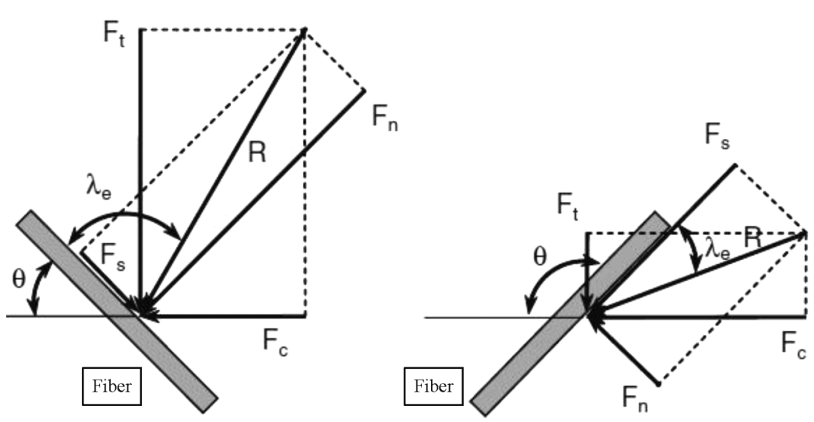

Figure 4: Cutting-force components along and perpendicular to the plane of fibers

Slika 4: Komponente sile rezanja vzdolž in pravokotno na ravnino vlaken

It is also shown in Figure $\mathbf{4}$ that the resultant force, $R$, makes an angle $\lambda_{\mathrm{e}}$ to the fiber orientation. The behavior of angle $\lambda_{\mathrm{e}}$ and normal force $F_{n}$ with the fiber orientation may be linked to the chip-formation mode. ${ }^{4}$

\subsection{Experimental design}

The Taguchi experimental design was used in order to determine the control parameters that affect the cutting force and surface roughness and to minimize the time and costs with the minimum number of tests. An orthogonal array for three factors at six levels was used for describing of experimental design (Table 4).

Table 4: Assignment of the levels to the factors Tabela 4: Opis nivojev in faktorjev

\begin{tabular}{|c|c|c|c|c|c|c|c|}
\hline \multirow{2}{*}{ Symbol } & \multirow{2}{*}{ Factors } & \multicolumn{6}{|c|}{ Level } \\
\hline & & 1 & 2 & 3 & 4 & 5 & 6 \\
\hline A & $\begin{array}{c}\text { Cutting tool } \\
\text { (carbide end mill) }\end{array}$ & $\mathrm{a}$ & b & $\mathrm{c}$ & d & e & $\mathrm{f}$ \\
\hline B & $\begin{array}{l}\text { Spindle speed } \\
\left(\min ^{-1}\right)\end{array}$ & 3800 & 4800 & 5800 & - & - & - \\
\hline $\mathrm{C}$ & $\begin{array}{l}\text { Feed rate } \\
(\mathrm{mm} / \text { tooth })\end{array}$ & 0.03 & 0.06 & 0.09 & - & - & - \\
\hline
\end{tabular}

The $L_{18}\left(6^{1} \times 3^{2}\right)$ array mixed type shown in Table 5 was determined with eighteen rows corresponding to the numbers of the tests and three columns at six levels. The factors and the interactions are designated to the columns.

The experimental design is made up of eighteen tests where the first column was designated to the test number, the second column to the carbide end mills (a,b,c,d,e,f), the third column to the spindle speed (rev/min) and the fourth column to the feed rate (mm/tooth).

An analysis of variance of the data realting to the cutting force, $F_{\mathrm{c}}(\mathrm{N})$ and surface roughness $R_{\mathrm{a}}(\mu \mathrm{m})$ for the CFRP material was made with the aim of analyzing the influence of the cutting tool (a carbide end mill), spindle speed $\left(\mathrm{min}^{-1}\right)$ and feed rate $(\mathrm{mm} /$ tooth$)$ on the total variance of the results.
Table 5: Orthogonal array $L_{18}\left(6^{1} \times 3^{2}\right)$

Tabela 5: Ortogonalna matrika $L_{18}\left(6^{1} \times 3^{2}\right)$

\begin{tabular}{|c|c|c|c|}
\hline $\begin{array}{c}L_{18} \\
\left(6^{1} \times 3^{2}\right) \text { test }\end{array}$ & $\begin{array}{l}\text { Cutting tools } \\
\text { (Carbide end } \\
\text { mills) }\end{array}$ & $\begin{array}{l}\text { Spindle speed } \\
\left(\min ^{-1}\right)\end{array}$ & $\begin{array}{l}\text { Feed rate } \\
(\mathrm{mm} / \text { tooth })\end{array}$ \\
\hline 1 & $\mathrm{a}$ & 3800 & 0.03 \\
\hline 2 & $\mathrm{a}$ & 4800 & 0.06 \\
\hline 3 & $a$ & 5800 & 0.09 \\
\hline 4 & $\mathrm{~b}$ & 3800 & 0.03 \\
\hline 5 & $\mathrm{~b}$ & 4800 & 0.06 \\
\hline 6 & $\mathrm{~b}$ & 5800 & 0.09 \\
\hline 7 & $\mathrm{c}$ & 3800 & 0.06 \\
\hline 8 & $\mathrm{c}$ & 4800 & 0.09 \\
\hline 9 & $\mathrm{c}$ & 5800 & 0.03 \\
\hline 10 & $\mathrm{~d}$ & 3800 & 0.09 \\
\hline 11 & $\mathrm{~d}$ & 4800 & 0.03 \\
\hline 12 & $\mathrm{~d}$ & 5800 & 0.06 \\
\hline 13 & $\mathrm{e}$ & 3800 & 0.06 \\
\hline 14 & $\mathrm{e}$ & 4800 & 0.09 \\
\hline 15 & $\mathrm{e}$ & 5800 & 0.03 \\
\hline 16 & $\mathrm{f}$ & 3800 & 0.09 \\
\hline 17 & $\mathrm{f}$ & 4800 & 0.03 \\
\hline 18 & $\mathrm{f}$ & 5800 & 0.06 \\
\hline
\end{tabular}

\section{RESULTS AND DISCUSSION}

The milling tests were conducted to evaluate the effect of the cutting parameters and cutting-tool properties (the helix angle, TiAl-coated or uncoated) on the cutting force and surface roughness for the $45^{\circ}$ fiber orientation angle. The cutting forces were determined with Equations (3) and (4). The value of the feed rate $(\mathrm{mm} / \mathrm{min})$ was calculated with Equation (5):

$$
f=f_{z} z n
$$

where $f_{z}$ is the feed per tooth, $z$ is the number of flutes and $n$ is the number of revolutions. The value of the surface roughness $(\mu \mathrm{m})$ was calculated with Equation (6) where $f$ is the amount of feed in $\mathrm{mm} / \mathrm{min}, r$ is the cutting-tool radius in $\mathrm{mm}$ and $R_{\mathrm{a}}$ is the average surface roughness $(\mu \mathrm{m}):^{18}$

$$
R_{\mathrm{a}}=\frac{f^{2}}{32 r}
$$

In this study, the Taguchi experimental design makes it possible to isolate the effects of individual machining parameters at different levels using either the average values of experimental outputs or their corresponding $S / N$ ratios. Herein, analyses of the effects of the machining parameters were performed on the basis of the $S / N$ ratios of the machinability outputs using response graphs and an analysis of variance (ANOVA). ANOVA was performed to determine the relative influence of the experimental parameters on each of the machinability outputs. This can be accomplished by calculating the variability of the computed $S / N$ ratio for each parameter and the associated error. 
In the Taguchi experimental design for a variable product or process and uncontrollable factors, the most suitable combinations of controllable-factor levels are selected and the variability of the product or process is optimized for a certain purpose as the smaller-the-better (SB), the nominal-the-best (NB) and the higher-thebetter (HB). ${ }^{19}$ The results obtained with the cutting tests are given in Table 6. The test results, obtained with the Taguchi experimental design were evaluated by converting them into the signal/noise $(S / N)$ ratio. $\mathrm{S} / \mathrm{N}$ values were calculated with the smaller-the-better Equation (7) because the stresses due to the parameters affecting the cutting force and surface roughness were desired at the lowest level. Here, $Y$ is the performance-characteristic value (the stress), $n$ is the number of $Y$ values. The values with the highest $S / N$ ratio among the levels of the factors in the tests created the best performance. Besides, the degrees of importance of the factors were investigated statistically on the test results with the variance analysis (ANOVA) and the best combination was determined with his study. ${ }^{20}$

Smaller-the-better:

$$
\frac{S}{N_{\mathrm{SB}}}=-10 \lg \left(\frac{1}{n} \sum_{i=1}^{n} y i^{2}\right)
$$

The cutting force is one of the most important output variables, created during the process and is directly affected by any variable. These variables, which affect the cutting forces are feed rate, depth of cut (radial and axial), cutting speed, tool and turning-chip geometry, workpiece material, tool-work interface dynamic characteristics, fixture system, development of the wear on the tool cutting surfaces, temperature and vibration. The cutting forces affecting the tool is an important data

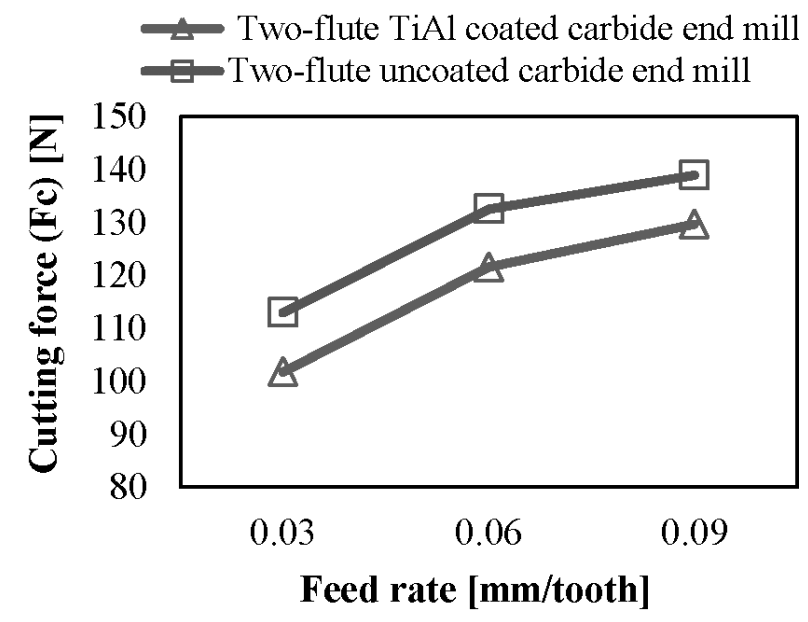

Figure 5: Variation of cutting forces depending on the cutting-tool type and feed rate

Slika 5: Spreminjanje sile rezanja $\mathrm{v}$ odvisnosti od vrste orodja in hitrosti podajanja

source for the condition of the tool. This information can be used for a better understanding of machinability, tool fracture, tool wear and surface integrity. ${ }^{21,22}$

The cutting forces created during the milling of the CFRP material with two-flute, $30^{\circ}$ helix-angled TiAlcoated and uncoated carbide end mills are shown in Figure 5.

In Figure 5, an increase in the cutting forces was observed for both the coated and uncoated carbide end mills, with the increasing feed rates depending on the constant depth of cut $\left(a_{\mathrm{p}}\right)$ and the number of revolutions $(n)$. This can be explained with the increase in the turning-chip volume per unit time with the increase in the feed rate. ${ }^{23}$ In their study ${ }^{24}$, the authors explain the

Table 6: Taguchi experimental design

Tabela 6: Taguchi načrt preskusa

\begin{tabular}{|c|c|c|c|c|c|c|c|}
\hline \multirow{2}{*}{$\begin{array}{l}\text { Experiment } \\
\text { number }\end{array}$} & \multirow{2}{*}{ A } & \multirow{2}{*}{ B } & \multirow{2}{*}{$\mathrm{C}$} & \multicolumn{2}{|c|}{$F_{\mathrm{c}}(\mathrm{N})$} & \multicolumn{2}{|c|}{$R_{\mathrm{a}}(\mu \mathrm{m})$} \\
\hline & & & & Cutting force $(\mathrm{N})$ & $S / N(\mathrm{~dB})$ & Surface roughness $(\mu \mathrm{m})$ & $S / N(\mathrm{~dB})$ \\
\hline 1 & $\mathrm{a}$ & 3800 & 0.03 & 101.8 & 40.1550 & 1.147 & 1.19127 \\
\hline 2 & $\mathrm{a}$ & 4800 & 0.06 & 121.6 & 41.6987 & 1.259 & 2.00051 \\
\hline 3 & $\mathrm{a}$ & 5800 & 0.09 & 129.7 & 42.2588 & 1.406 & 2.95971 \\
\hline 4 & $\mathrm{~b}$ & 3800 & 0.03 & 113 & 41.0616 & 1.179 & 1.43028 \\
\hline 5 & $\mathrm{~b}$ & 4800 & 0.06 & 132.6 & 42.4509 & 1.231 & 1.80516 \\
\hline 6 & $\mathrm{~b}$ & 5800 & 0.09 & 139 & 42.8603 & 1.263 & 2.02807 \\
\hline 7 & $\mathrm{c}$ & 3800 & 0.06 & 98 & 39.8245 & 1.400 & 2.92256 \\
\hline 18 & $\mathrm{c}$ & 4800 & 0.09 & 117.8 & 41.4229 & 1.647 & 4.33387 \\
\hline 9 & $\mathrm{c}$ & 5800 & 0.03 & 91.3 & 39.2094 & 1.078 & 0.65238 \\
\hline 10 & $\mathrm{~d}$ & 3800 & 0.09 & 130.8 & 42.3322 & 1.581 & 3.97864 \\
\hline 11 & $\mathrm{~d}$ & 4800 & 0.03 & 113.3 & 41.0846 & 1.093 & 0.77240 \\
\hline 12 & $\mathrm{~d}$ & 5800 & 0.06 & 133.2 & 42.4901 & 1.420 & 3.04577 \\
\hline 13 & $\mathrm{e}$ & 3800 & 0.06 & 112.8 & 41.0462 & 1.191 & 1.51824 \\
\hline 14 & $\mathrm{e}$ & 4800 & 0.09 & 96.2 & 39.6635 & 1.367 & 2.71537 \\
\hline 15 & $\mathrm{e}$ & 5800 & 0.03 & 101.8 & 40.1550 & 1.181 & 1.44500 \\
\hline 16 & $\mathrm{f}$ & 3800 & 0.09 & 115.9 & 41.2817 & 1.544 & 3.77295 \\
\hline 17 & $\mathrm{f}$ & 4800 & 0.03 & 96.4 & 39.6815 & 1.173 & 1.38596 \\
\hline 18 & $\mathrm{f}$ & 5800 & 0.06 & 160.8 & 44.1257 & 1.309 & 2.33879 \\
\hline
\end{tabular}


impact of the axial and tangential feed rates per tooth on the process forces. They also noticed an increase in the cutting forces with the increasing feed rates. In another study, they also described an increase in the cutting temperatures with the cutting forces. As a result, undesirable thermal stresses occurred in the cutting tool and the workpiece. The maximum cutting temperature of $44^{\circ} \mathrm{C}$ was reported for the cutting speed of $35 \mathrm{~m} / \mathrm{min}$ and feed rate of $0.178 \mathrm{~m} / \mathrm{min} .{ }^{25}$ It referred to a glass-fiber-reinforced laminate that was machined with a PCD tool. It is seen that at low and moderate feed rates per tooth, only slight increases in the normal force occur over a cuttingspeed range of $1200-2400 \mathrm{~m} / \mathrm{min}$. In these tests, the cutting force increased due to the cutting-tool coating process. The coating on the cutting tool increased the hardness and strength of the cutting tool. ${ }^{26}$ Besides, the cutting-tool coating caused a lower frictional coefficient and, as a result, the cutting forces of the coated tools were lower. ${ }^{27}$ In relation with this, the lowest cutting force was determined for the coated tool at the lowest feed rate $(0.03 \mathrm{~mm} /$ tooth $){ }^{26}$

Depending on the constant depth of cut and the number of revolutions, the surface roughness created during the milling of the CFRP material with the two-flute carbide end mill is given in Figure 6.

As shown in Figure 6, when the coated and uncoated carbide end mills were compared with respect to the surface roughness, the roughness values at the feed rates of 0.03 and $0.06 \mathrm{~mm} /$ tooth came out to be very close to each other whereas, at higher feed rates, a better surface quality was obtained with the uncoated carbide end mills. They also confirmed in their study that the surface roughness decreased with an increase in the cutting speed, but no critical speed could be identified. This could have been due to the fact that the cutting speed range used in these studies was below the critical cutting speed. All of the experimental studies confirm that the

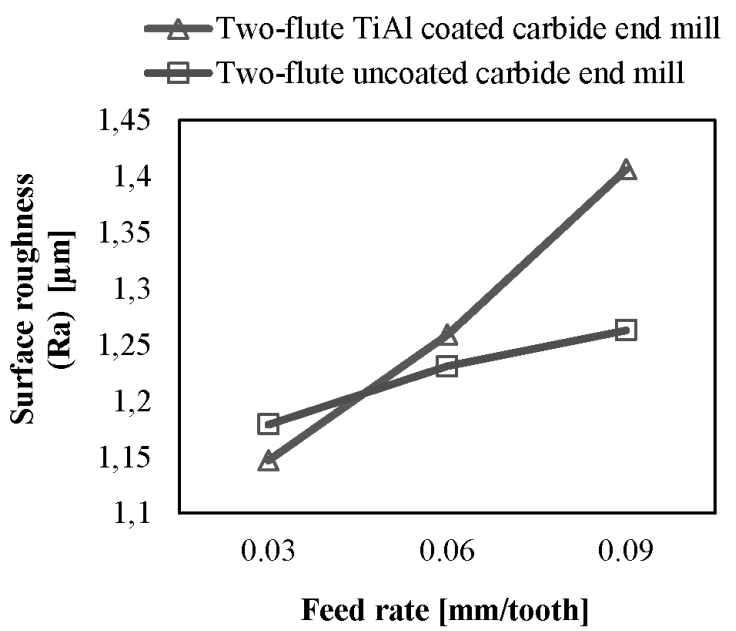

Figure 6: Variation of the surface roughness depending on the cutting-tool type and feed rate

Slika 6: Spreminjanje hrapavosti površine, v odvisnbosti od vrste orodja za rezanje in hitrosti podajanja feed rate is the most influential factor in determining the surface roughness. In these tests, the cutting-tool coating causes a thickening in the form of a cutting edge and the cutting tool ruptures the fibers rather than cutting them, which causes the coating and the workpiece to chemically react. For this reason, in the tests carried out with the coated cutting tools, the surface roughness was higher compared to the uncoated tools. ${ }^{28}$ They also pointed out in their study that the feed rate is the cutting parameter which has a greater influence on the surface roughness (33.43 per cent) when milling GFRP composite materials with solid carbide coated with PCD. ${ }^{29}$

Depending on the constant depth of cut and the number of revolutions, the surface roughness created during the milling of the CFRP material with all of the carbide end mills is given in Figure 7.

An increase in the surface roughness with the increase in the feed rates was observed for all the carbide end mills (Figure 7). It was specified that this was an expected result and was also present in the literature. They also found that the surface roughness increases with the increase in the feed rate. In these tests, it was also observed that there was an increase in the surface roughness with the increase in the number of flutes and the helix angle. ${ }^{30}$ Depending on the increasing feed rates, the best surface quality in all the tests was obtained with the two-flute $30^{\circ}$ helix-angled uncoated carbide end mill. It was specified that the increase in the number of flutes and helix angles adversely affected the surface quality. According to another study, the feed rate is also the most significant factor affecting the surface roughness. ${ }^{31}$

Even the wear of the machining edge causes a high increase in the cutting resistance, which, in turn, leads to a plastic strain of the surface layers of the sample and delamination. What may be observed here is a correlation between the delamination size and the feed rate and cutting speed. Every single growth of these quantities translates into an increase in the cutting forces and an increase in the surface roughness. Figure $\mathbf{8}$ shows a selected microscope photograph of the milling surface (the speed of cutting is fixed, while the feed rate is changeable).
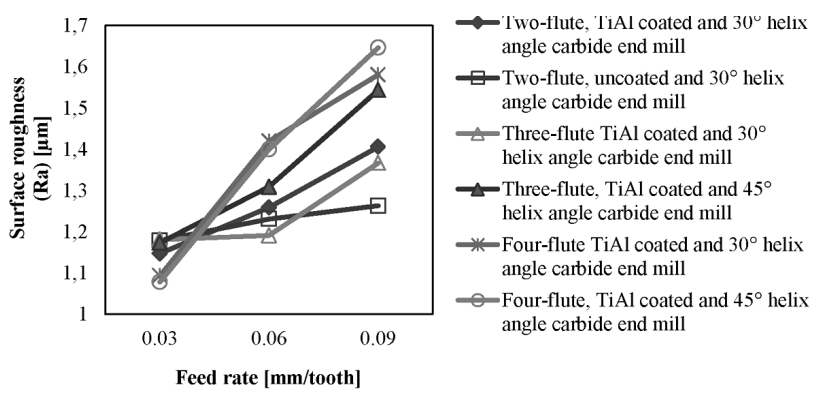

Figure 7: Feed rate/surface roughness relationship for all carbide end mills used in the tests

Slika 7: Odvisnost hitrosti podajanja in hrapavosti površine za vse karbidne rezkarje uporabljene v preskusu 


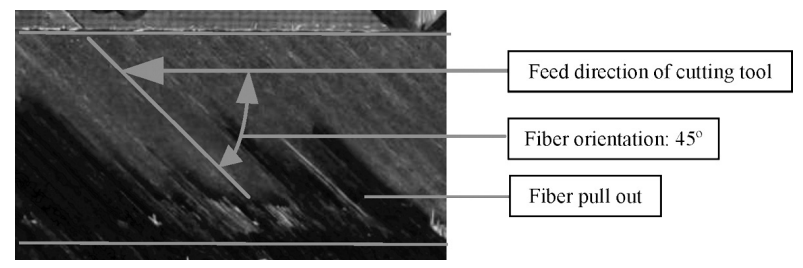

Figure 8: Cutting and feed direction for the $45^{\circ}$ fiber orientation Slika 8: Smer rezanja in podajanja pri orientaciji vlaken $45^{\circ}$

\subsection{Analysis of variance (ANOVA)}

The experimental design and statistical analysis (ANOVA) were made with respect to a mixed-level design through the Minitab 15.0 software. According to the ANOVA analysis of the cutting force (Table 7), the feed rate had the highest effect with a $53.06 \%$ ratio. The effects of the cutting tool and the number of revolutions were $22.93 \%$ and $16.17 \%$, respectively. In the ANOVA analysis of the surface roughness (Table 8), the feed rate again had the highest effect with a $86.01 \%$ ratio and the effects of the cutting tool and the number of revolutions were low.

On the basis of the test results, $S / N$ ratios and optimum parameters were estimated. In Figures 9 and 10, the $S / N$ ratio graphs of control factors are given depending on the cutting force and surface roughness. In Figure 9, the cutting parameters for the cutting force, obtained through the Taguchi optimization were found to be " $\mathrm{A}_{3} \mathrm{~B}_{1} \mathrm{C}_{1}$ " (four-flute and $45^{\circ}$ helix-angled, TiAl-coated carbide end mill, $3800 \mathrm{rpm}$ and a feed rate of 0.03 $\mathrm{mm} /$ tooth). It was assumed that the highest $S / N$ ratio of each parameter indicated the optimum level of that parameter. ${ }^{19}$ The obtained parameters in the optimization of the surface roughness were $" \mathrm{~A}_{2} \mathrm{~B}_{3} \mathrm{C}_{1}$ " (two-flute $30^{\circ}$ helix-angled uncoated carbide end mill, $5800 \mathrm{rpm}, 0.03$ $\mathrm{mm} /$ tooth) as seen in Figure 10. When the optimization

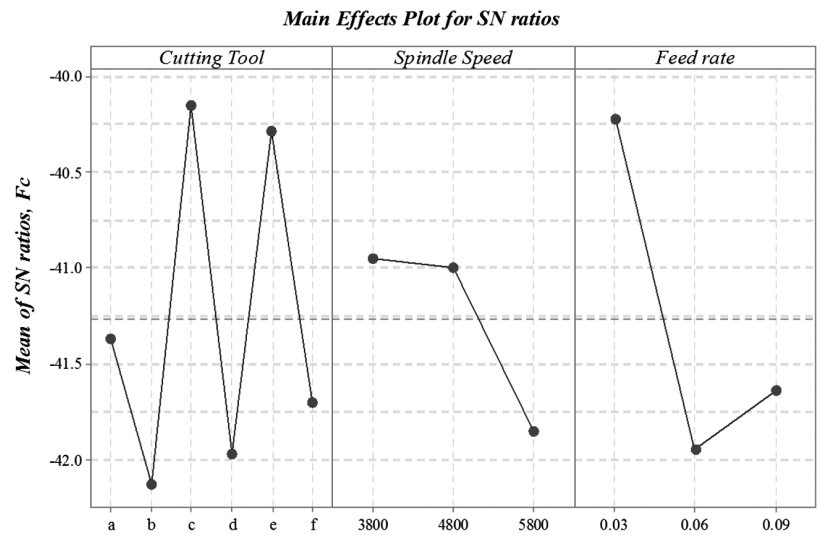

Figure 9: Signal/noise ratios for cutting forces

Slika 9: Razmerja signal/hrup pri silah rezanja

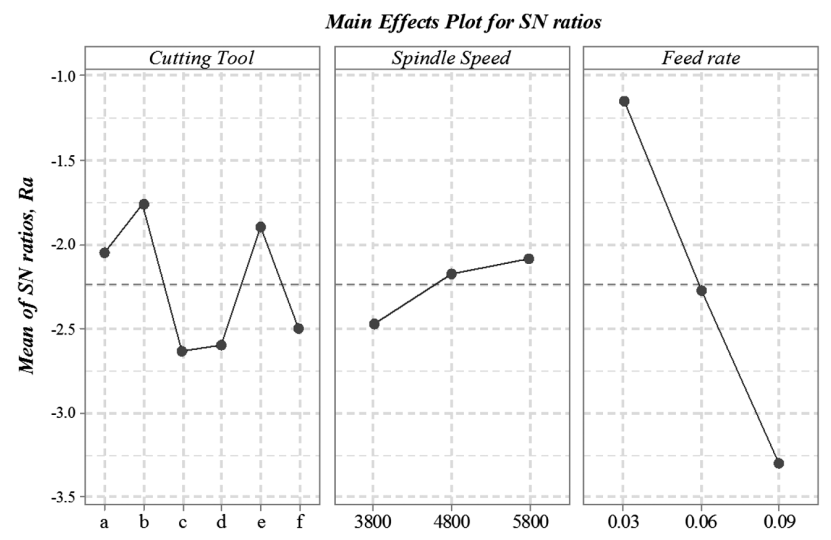

Figure 10: Signal/noise ratios for the surface roughness Slika 10: Razmerja signal/hrup pri hrapavosti površine

process was evaluated, it was observed that although the cutting tools with a large helix angle and many cutting edges came out to be better with respect to the cutting forces, the cutting tools with a small helix angle and few

Table 7: ANOVA results for cutting forces

Tabela 7: ANOVA rezultati sil rezanja

\begin{tabular}{|c|c|c|c|c|c|c|c|}
\hline & $\begin{array}{c}\text { Cutting } \\
\text { parameters }\end{array}$ & $\begin{array}{c}\text { Degrees of } \\
\text { freedom }\end{array}$ & $\begin{array}{c}\text { Sequential sum } \\
\text { of squares }\end{array}$ & $\begin{array}{c}\text { Average } \\
\text { correction }\end{array}$ & $\begin{array}{c}\text { Means of } \\
\text { squares }\end{array}$ & $\begin{array}{c}\text { Percentage } \\
\text { contribution }\end{array}$ \\
\hline A & Cutting tool & 5 & 10.87 & 10.87 & 2.174 & 0.086 & $22.93 \%$ \\
\hline B & Spindle speed & 2 & 3.067 & 3.067 & 1.5337 & 0.189 & $16.17 \%$ \\
\hline C & Feed rate & 2 & 10.052 & 10.052 & 5.0262 & 0.019 & $53.06 \%$ \\
\hline Error & & 8 & 5.945 & 5.945 & 0.7431 & \\
\hline Total & & 17 & 29.934 & & & \\
\hline
\end{tabular}

Table 8: ANOVA results for surface roughness

Tabela 8: ANOVA rezultati za hrapavost površine

\begin{tabular}{|c|c|c|c|c|c|c|c|}
\hline & $\begin{array}{c}\text { Cutting } \\
\text { parameters }\end{array}$ & $\begin{array}{c}\text { Degrees of } \\
\text { freedom }\end{array}$ & $\begin{array}{c}\text { Sequential sum } \\
\text { of squares }\end{array}$ & $\begin{array}{c}\text { Average } \\
\text { correction }\end{array}$ & $\begin{array}{c}\text { Means of } \\
\text { squares }\end{array}$ & $\begin{array}{c}\text { Percentage } \\
\text { contribution }\end{array}$ \\
\hline A & Cutting tool & 5 & 2.2355 & 2.2355 & 0.4471 & 0.477 \\
\hline B & Spindle speed & 2 & 0.5018 & 0.5018 & 0.2509 & 0.593 & $3.09 \%$ \\
\hline C & Feed rate & 2 & 13.9017 & 13.9017 & 6.9509 & 0.002 & $86.01 \%$ \\
\hline Error & & 8 & 3.5904 & 3.5904 & 0.4488 & \\
\hline Total & & 17 & 20.2295 & & & \\
\hline
\end{tabular}


flutes gave better results from the point of the surface roughness and delamination.

\subsection{Confirmation tests}

After obtaining the best estimation results for the Taguchi optimization, validation tests were made to verify the optimization. In the Taguchi experimental design, the next step after the selection of the optimum levels of the test parameters is the estimation of the measurement result for the optimum parameter and the determination of the difference by comparing it with the actual measurement. ${ }^{32,33}$

The determined optimum parameters of " $A_{3} B_{1} C_{1}$ " and " $\mathrm{A}_{2} \mathrm{~B}_{3} \mathrm{C}_{1}$ " for the cutting force and surface roughness and the results of the verification tests were compared (Tables 9 and 10). There was a good consistency between the actual and estimated values for both of the two performance characteristics (the cutting force and the surface roughness). As for the optimum cutting parameters obtained with the Taguchi application, there were improvements of $0.8536 \mathrm{~dB}$ and $0.3249 \mathrm{~dB}$ for the cutting force and surface roughness according to the $S / N$ ratios in comparison with the original parameters.

Table 9: Verification test results for cutting force

Tabela 9: Rezultati preskusov preverjanja sile rezanja

\begin{tabular}{|c|c|c|c|}
\hline & \multirow{2}{*}{$\begin{array}{c}\text { Starting cutting } \\
\text { parameters }\end{array}$} & Optimum cutting parameters \\
\cline { 3 - 4 } & $\mathrm{A}_{1} \mathrm{~B}_{2} \mathrm{C}_{3}$ & $\mathrm{~A}_{3} \mathrm{~B}_{1} \mathrm{C}_{1}$ & $\mathrm{~A}_{3} \mathrm{~B}_{1} \mathrm{C}_{1}$ \\
\hline Level & 101.5 & 83.35 & 92 \\
\hline $\begin{array}{c}\text { Cutting force } \\
(\mathrm{N})\end{array}$ & -40.1293 & -38.7934 & -39.2757 \\
\hline$S / N$ ratio $(\mathrm{dB})$ & $0.8536 \mathrm{~dB}$ \\
\hline $\begin{array}{c}\text { Improvement } \\
\text { of } S / N \text { ratio }\end{array}$ & & 0.4823 \\
\hline $\begin{array}{c}\text { Prediction } \\
\text { error }(\mathrm{dB})\end{array}$ & & \multicolumn{3}{|c}{} \\
\hline
\end{tabular}

Table 10: Verification test results for surface roughness Tabela 10: Rezultati preskusov preverjanja hrapavosti površine

\begin{tabular}{|c|c|c|c|}
\hline & \multirow{2}{*}{$\begin{array}{c}\text { Starting } \\
\text { cutting } \\
\text { parameters }\end{array}$} & \multicolumn{2}{|c|}{$\begin{array}{c}\text { Optimum cutting } \\
\text { parameters }\end{array}$} \\
\cline { 3 - 4 } & $\mathrm{A}_{1} \mathrm{~B}_{2} \mathrm{C}_{2}$ & $\mathrm{~A}_{2} \mathrm{~B}_{3} \mathrm{C}_{1}$ & $\mathrm{~A}_{2} \mathrm{~B}_{3} \mathrm{C}_{1}$ \\
\hline Level & 1.259 & 1.034 & 1.207 \\
\hline $\begin{array}{c}\text { Surface roughness } \\
\left(R_{\mathrm{a}}, \mu \mathrm{m}\right)\end{array}$ & 2.00 & -0.5015 & -1.6741 \\
\hline$S / N$ ratio $(\mathrm{dB})$ & & $0.3249 \mathrm{~dB}$ & \\
\hline $\begin{array}{c}\text { Improvement of } \\
S / N \text { ratio }\end{array}$ & & 1.1726 \\
\hline $\begin{array}{c}\text { Prediction error } \\
(\mathrm{dB})\end{array}$ & & \multicolumn{3}{|}{} \\
\hline
\end{tabular}

According to the data obtained from the verification tests, a high consistency was observed between the estimated and experimental values in the optimization of the cutting force and surface roughness and the effectiveness of the Taguchi optimization was proved with this study.

\section{CONCLUSIONS}

In this study, a CFRP material was milled with several carbide end mills, and the cutting force and surface roughness for a $45^{\circ}$ fiber orientation angle were investigated. The Taguchi optimization and ANOVA were applied to the experimental data. The conclusions from these processes can be listed as follows:

- For all of the carbide end mills, an increase in both the cutting force and surface roughness was observed depending on the increasing feed rate.

- In the tests with an uncoated carbide end mill, a better surface quality and less delamination were obtained.

- As for the cutting tools, there was an increase in the surface roughness as the number of flutes and the helix angle increased.

- At the end of the Taguchi optimization of the cutting force, suitable cutting parameters for the four-flute $45^{\circ}$ helix-angled TiAl-coated carbide end mill $\left(\mathrm{A}_{3} \mathrm{~B}_{1} \mathrm{C}_{1}\right)$ were found to be $3800 \mathrm{~min}^{-1}$ and a feed rate of $0.03 \mathrm{~mm} /$ tooth.

- At the end of the Taguchi optimization, suitable cutting parameters for the two-flute $30^{\circ}$ helix-angled uncoated carbide end mill $\left(\mathrm{A}_{2} \mathrm{~B}_{3} \mathrm{C}_{1}\right)$ were found to be $5800 \mathrm{~min}^{-1}$ and a feed rate of $0.03 \mathrm{~mm} /$ tooth.

- The lowest cutting forces were obtained for the cutting tools with the highest number of flutes and the largest helical angles, whereas the best surfaceroughness values were obtained with the cutting tools with a low number of flutes and acute helix angles.

- At the end of the tests, when ANOVA was applied to the obtained data, the most effective parameter for the cutting force and surface roughness was the feed rate.

- The optimum parameters that were obtained as a result of the Taguchi optimization and the estimated cutting-force and surface-roughness values were compared by performing validation tests. This comparison indicated a high consistency between the values.

\section{Acknowledgement}

This study was accomplished with the support of Gazi University Scientific Research Project no 07/2010-18. Authors thank the Gazi University Scientific Research Unit for their support.

\section{REFERENCES}

${ }^{1}$ D. Kalla, J. Sheik-Ahmad, J. Twomey, Prediction of Cutting Forces in Helical End Milling Fiber Reinforced Polymers, International Journal of Machine Tools \& Manufacture, 50 (2010) 10, 882-891, doi:10.1016/j.ijmachtools.2010.06.005

${ }^{2}$ M. Ramulu, Characterization of surface quality in machining of composites, In: S. Jahanmir, M. Ramulu, P. Koshy (Eds.), Machining of Ceramics and Composites, Marcel Dekker, New York 1999, 575-648 
${ }^{3}$ E. Erisken, Influence from production parameters on the surface roughness of a machined short fibre reinforced thermoplastic, International Journal of Machine Tools \& Manufacture, 39 (1999) 10, 1611-1618, doi:10.1016/S0890-6955(99)00017-6

${ }^{4}$ J. Y. Sheikh-Ahmad, Machining of Polymer Composites, Springer, 2009

${ }^{5}$ J. P. Davim, P. Reis, Damage and Dimensional Precision on Milling Carbon Fiber-Reinforced Plastics Using Design Experiments, Journal of Materials Processing Technology, 160 (2005) 2, 160-167, doi:10.1016/j.jmatprotec.2004.06.003

${ }^{6}$ P. S. Sreejith, R. Krishnamurthy, S. K. Malhota, K. Narayanasamy, Evaluation of PCD tool performance during machining of carbon/ phenolic ablative composites, Journal of Material Processing Technology, 104 (2000) 1-2, 53-58, doi:10.1016/S0924-0136(00) 00549-5

R. Rusinek, Cutting Process of Composite Materials: An Experimental Study, International Journal of Non-Linear Mechanics, 45 (2010) 4, 458-462, doi:10.1016/j.ijnonlinmec.2010.01.004

${ }^{8}$ D. Berger, F. Bleicher, C. Dorn, F. Puschitz, Optimised Machining of Fibre Reinforced Material, Daaam International Scientific Book, 3 (2008), 27-34, doi:10.2507/daaam.scibook.2008.03

${ }^{9}$ Ö. Erkan, B. Ișık, Investigation of Cutting Parameter Effects on Surface Roughness During Machining of Glass Fiber Reinforced Plastic Composite Material, $5^{\text {th }}$ International Advanced Technologies Symposium (IATS 09), Karabük, Turkey 2009, 1414-1419

${ }^{10}$ N. Naresh, M. P. Jenarthanan, R. H. Prakash, Multi-objective optimisation of CNC milling process using Grey-Taguchi method in machining of GFRP composites, Multidiscipline Modeling in Materials and Structures, 10 (2014) 2, 265-275, doi:10.1108/MMMS06-2013-0042

${ }^{11}$ J. P. Davim, J. C. Rubio, A. M. Abrao, A Novel Approach Based on Digital Image Analysis to Evaluate the Delamination Factor after Drilling Composite Laminates, Composite Science and Technology, 67 (2007) 9, 1939-1945, doi:10.1016/j.compscitech.2006.10.009

${ }^{12}$ S. R. Karnik, V. N. Gaitonde, J. C. Rubio, A. E. Correia, A. M. Abrao, J. P. Davim, Delamination Analysis in High Speed Drilling of Carbon Fiber Reinforced Plastics (CFRP) Using Artificial Neural Network Model, Materials and Design, 29 (2008) 9, 1768-1776, doi:10.1016/j.matdes.2008.03.014

${ }^{13}$ C. C. Tsao, H. Hocheng, Effect of Tool Wear on Delamination in Drilling Composite Materials, International Journal of Mechanical Sciences, 49 (2007) 8, 983-988, doi:10.1016/j.ijmecsci.2007.01.001

${ }^{14}$ S. K. Kim, G. D. Lee, K. Y. Kwak, S. Namgung, Machinability of Carbon Fiber-Epoxy Composite Materials in Turning, Journal of Materials Processing Technology, 32 (1992) 3, 553-570, doi:10.1016/0924-0136(92)90253-O

${ }^{15}$ N. S. Hu, L. C. Zhang, Some Observations in Grinding Unidirectional Carbon-Fibre-Reinforced Plastics, Journal of Materials Processing Technology, 152 (2004) 3, 333-338, doi:10.1016/ j.jmatprotec.2004.04.374

${ }^{16}$ T. Kaneeda, CFRP cutting mechanism, Transactions of the North American Manufacturing Research Institute of SME 19, 1991, 216-221

${ }^{17}$ H. Takeyama, N. Iijima, Machinability of glass-fiber-reinforced plastics and application of ultrasonic machining, CIRP Annals - Manufacturing Technology, 37 (1988) 1, 93-96, doi:10.1016/S00078506(07)61593-5
${ }^{18}$ M. Stephen, Grinding Technology, Society of Manufacturing Engineers, Industrial Press, New York 1989

${ }^{19}$ N. S. Mohan, S. M. Kulkarni, A. Ramachandra, Delamination analysis in drilling process of glass fiber reinforced plastic (GFRP) composite materials, Journal of Materials Processing Technology, 186 (2007) 1-3, 265-271, doi:10.1016/j.jmatprotec.2006.12.043

${ }^{20}$ G. Taguchi, S. Chowdhury, Y. Wu, Taguchi's Quality Engineering Handbook, Wiley-Interscience, New Jersey, USA 2004

${ }^{21}$ R. A. Kishore, R. Tiwari, A. Dvivedi, I. Singh, Taguchi analysis of the residual tensile strength after drilling in glass fiber reinforced epoxy composites, Materials and Design, 30 (2009) 6, 2186-2190, doi:10.1016/j.matdes.2008.08.035

${ }^{22}$ K. Palanikumara, J. P. Davim, Assessment of some factors influencing tool wear on the machining of glass fibre-reinforced plastics by coated cemented carbide tools, Journal of Materials Processing Technology, 209 (2009) 1, 511-519, doi:10.1016/j.jmatprotec.2008. 02.020

${ }^{23}$ H. Hocheng, H. Y. Puw, Y. Huang, Preliminary study on milling of unidirectional carbon fibre-reinforced plastics, Composites Manufacturing, 4 (1993) 2, 103-108, doi:10.1016/0956-7143(93)90077-L

${ }^{24}$ B. Denkena, D. Boehnke, J. H. Dege, Helical milling of CFRP titanium layer compounds, CIRP Journal of Manufacturing Science and Technology, 1 (2008) 2, 64-69, doi:10.1016/j.cirpj.2008.09.009

${ }^{25}$ M. Ucar, Y. Wang, End-milling machinability of a carbon fiber reinforced laminated composite, Journal of Advanced Materials, 37 (2005) 4, 46-52

${ }^{26}$ W. Konig, C. H. Wulf, P. Grab, H. Willerscheid, Machining of fibre reinforced plastics, Annals of CIRP, 34 (1985), 537-547

${ }^{27}$ E. P. DeGarmo, J. T. Black, R. A. Kohser, Materials and Processes in Manufacturing, Prentice-Hall Inc., New Jersey 1997

${ }^{28}$ J. P. Davim, P. Reis, Multiple regression analysis (MRA) in modelling milling of glass fiber reinforced plastics (GFRP), International Journal of Manufacturing Technology and Management, 6 (2004) 1-2, 185-197, doi:10.1504/IJMTM.2004.004514

${ }^{29}$ M. P. Jenarthanan, R. Jeyapaul, N. Naresh, Modelling and analysis of factors influencing surface roughness and delamination of milling of GFRP laminates using RSM, Multidiscipline Modeling in Materials and Structures, 8 (2012) 4, 489-504, doi:10.1108/15736101211281 588

${ }^{30}$ J. R. Ferreira, N. L. Coppini, G. W. A. Miranda, Machining optimisation in carbon fibre reinforced composite materials, Journal of Materials Processing Technology, 92-93 (1999), 135-140, doi:10.1016/S0924-0136(99)00221-6

${ }^{31}$ K. Ogawa, E. Aoyama, H. Inoue, T. Hirogaki, H. Nobe, Y. Kitahara, T. Katayama, M. Gunjima, Investigation on cutting mechanism in small diameter drilling for GFRP (thrust force and surface roughness at drilled hole wall), Composite Structures, 38 (1997) 1-4, 343-350, doi:10.1016/S0263-8223(97)00069-X

${ }^{32}$ V. Krishnaraj, A. Prabukarthi, A. Ramanathan, N. Elanghovan, M. S. Kumar, R. Zitoune, J. P. Davim, Optimization of machining parameters at high speed drilling of carbon fiber reinforced plastic (CFRP) laminates, Composites: Part B, 43 (2012) 4, 1791-1799, doi:10.1016/j.compositesb.2012.01.007

${ }^{33}$ G. D. Babu, K. S. Babu, B. U. M. Gowd, Effect of Machining Parameters on Milled Natural-Fiber-Reinforced Plastic Composites, Journal of Advanced Mechanical Engineering, 1 (2013), 1-12, doi:10.7726/jame.2013.1001 